\title{
Impoliteness Strategies and Gender Differences among Disney Modern Protagonists
}

\author{
Fatima Zohra Benabdellah \\ PhD Student, Department of English, Faculty of Foreign Languages, \\ University of Mostaganem, Algeria.
}

\begin{abstract}
Disney Animation industry has grown, over the years, as a powerful producer of youth media and generator of visual culture. Its animation films break into the world's living-room screens and mesmerize young spectators with a fantasy world full of life, magic and colors, where love and happiness are everlasting. The genre of anime, through a series of images, creates a link between the child and characters; a desirable image of self-seeing oneself reflected and experienced by the story characters, mediates how the spectator wants to be seen by others. Hence, these fe/male protagonists cross from being plain characters to become "Role Models" promoting impolite social norms and gender performances through their discursive practices. This research is concerned with the study of how modern fe/male highest grossing Disney characters use language to shape social identities through their impolite discourse and gender behaviors; By drawing on Culpeper's (2010) 'Model of Impoliteness Formulae'. The results of the model will be further examined with language and gender theories in order to uncover how both genders (females and males) use impoliteness strategies to re/produce and maintain their power relations.
\end{abstract}

Keywords: Disney, role models, impoliteness, gender, power

\section{Introduction}

Modern families seem to be categorized by unavailable parents and attention striving children. These parents devote their time to their career pursuit, house chores, and social events leaving no actual time to deal with their children. Here, they turn into 'Disney' the perfect babysitter without taking as much time to decipher what their children are being exposed to on a regular basis (Binkley, 2016). Disney has managed to establish a trustworthy reputation and a strong relationship with youngsters respectively their parents (Lederer, 2012). It cast a spell on viewers around the universe, be them children or older family members. These families consume the cultural input which the company transmits. Therefore, we moved from talking about pop-culture to 'Disney's culture'. The corporation perpetuates messages about sex, gender, power relations, social virtues, family values, and cultural norms to children across the world (Wieresma, 2000). Preschoolers, for instance, spend up to five hours a day viewing Disney animations (Romer, 1989). According to (Chen, 2006) animation can be described as a motion picture that utilizes a compilation of cinematic productions. These movies are broadcast on television, cinemas, social media and DVD merchandise. Anime stories are woven in a fantasy world filled with magic, fairytale love, and glee. They fascinate young viewers with powerful characters who live adventurous shadow days but manage to find the strength to overcome danger and fight evil. The films revolve around themes of friendship, love, self-discovery, courage, and sacrifice. Walt Disney Company seemed to be a pioneer in terms of animation. After the production of Snow White and the Seven Dwarves in 1937, Disney has captivated youth with its very first full-length romance masterpiece. Hence, it has monopolized the industry ever since. Disney's name started collocating with children entertainment and family leisure time (Lederer, 2012). Its animated features entertain children and set their imagination to go wild. These movies are fairytale 
adaptations with fascinating characters and dreamy songs that enshrine in our childhood memories forever (Lippi-Green, 2012).

Anime genre, more particularly, princess movies are learning tools directed to appeal youth through the creation of 'Role Model' characters and catchy tunes (Azmi, Ab Rashid; Abd Rahman, Basirah, 2016). The lead characters are powerful influencers. Their fantasy lives teach children appropriate ways of being and behaving (Lacroix, 2004).The films, though seemingly innocent, are loaded with tokens about gender portrayals, social manners and power relations among male and female protagonists. Disney has articulated through its iconic characters how females should be like and what is expected of them. And, how males should be like and what is expected of them. It sets the standards of appropriate and inappropriate ways of being accepted social actors. By spending hours consuming the supposedly innocent princess films, children get engaged in passive learning. That is internalizing the images drawn in the films which dictates how 'Role Model' males and females look-like, talk, feel and build relationships. Children are not 'blank slates'; they are rather active processors of animation content. They observe, internalize, categorize and act accordingly (Soares, 2017). "Media is a major educator in child's life" (Binkley, 2016.p.11). It plays an eminent role in children's learning processes especially at a very young age (Ahmed and Abdul Wahab, 2014). Any deviation of such representations is to be sanctioned by peers and society. Thus, children start to see the world through Disney's eyes. Wohlwend (2012) claims that Disney shapes the minds of young viewers. It teaches girls to act like princesses and boys to act like the saviors of the day. It inspires them to perform their femininity and masculinity appropriately. Masculinity is defined as being physically strong, authoritative, competitive, emotionally distant, impolite and independent. Femininity, on the other hand, is associated with being physically attractive, physically weak, demure, ultra-polite, subservient, emotional, nurturing, and dependent. These roles are essential for upholding power relations. Power can be defined as: "a property of relations between social groups, institutions or organizations"(Van Dijk 1996, p.84). He goes further to introduce dominance to be "understood as a form of social power abuse... as a legally or morally illegitimate exercise of control over others in one's own interest, often resulting in social inequality." (Van Dijk 1996, p.84).

Researchers in the field Such as Thompson and Zerbinos, 1995; Wieresma, 2000; Towbin et al, 2003; Lacroix, 2004; England et al, 2001;Binkley;2016, have opted for content analysis solely to draw conclusions about gender portrayals in Disney princess movies. They sought how femininities and masculinities are represented and juxtaposed. Thompson and Zerbinos (1995) see that Disney characters have changed along the years; whereas; Wieresma (2000) points out that power asymmetries, gender stereotypes, and traditional femininities and masculinities are still prevalent in Disney catchy tunes. England et al. (2016) echoe the same view stating that female characters continue to be portrayed under polite princess language use and traditional feminine gender roles; unlike males who are allowed more room to exercise their power, masculinity and inadequate social speech productions. This study intends to go further than reporting politeness and impoliteness as collateral attributes to gender and language use. We are interested to analyze what protagonists produce linguistically and what they do with language to gain power over the other. In a sense to decipher what rules govern their linguistic choices in social interaction and what is the impact of such choices?

Talking about princes and princesses entails their outstanding knowledge of etiquette. We imagine that they abide by the code of social manners and grace manuals par excellence. Being Disney fans ourselves, we were programmed to think that princesses always look perfect, speak gently, sing beautifully, walk and sit gracefully, eat with small bites, never raise their voices, and never giggle. They smile and whisper instead. We were set up to imagine princes to be handsome, clean and gentlemen. They must save their ladies, love them happily ever after, be noble to women, know how to sword-fight and dance in balls. Yet, From Snow White in 1937 till Moana 2016, Disney protagonists have noticeably evolved in terms of body image, aspirations, gender performances and discursive practices (Guizerix, 2013). Unlike their predecessors, Third generation protagonists are more independent, out-going, pursuing their dreams, less gentle and graceless. They avoid asking for help from their counterparts. They are "strong-willed, adventurous and bold."(Azmi et al., 2016. p.2). The paper at hand investigates what is beyond the postulations of politeness which are protagonists' impolite social interactions. This 
study aims to shed light on impoliteness usage among Disney modern lead characters, in order to, comprehend the extent to which these protagonists transgress normative social manners, and negotiate power relations. It might break the spell and encourage parents to co-view their content. The paper analyzes two modern animation movies Frozen 2013 and Moana 2016, drawing on Culpeper's (2010) 'Model of Impoliteness Formulae'. The findings will be further examined with language and gender theories so that to uncover how both genders (females and males) use impoliteness strategies to re/produce and maintain their power relations.

\section{This study attempts to answer the following research questions:}

1. Does Disney create impolite protagonists?

2. How do modern lead-characters maintain power relations?

\section{Impoliteness}

Communication is the essence of language. Humans use language to convey certain meanings, values, beliefs, and attitudes. Language users are selective of their speech productions. They are bound to given contexts, social distance, and degree of familiarity with the addressee. As social beings, we were brought up in a social setting. We learned from the social group appropriate and inappropriate speech formulas. Thereof, the way we approach someone at a party is definitely not the same as we consult an attorney. This is what 'Pragmatics' is all about. Pragmatics stands for "the study of linguistic acts and the context in which they are performed... it characterizes the features of the speech context which help determine which proposition is expressed by a given sentence" (Stalnaker, 1972 .p.383). Pragmatics encompasses the study of politeness and impoliteness among other research scopes. Social actors use language to do things, for example, perform work tasks, order food, and build relationships. Or, they employ it to make certain events happen, for instance, marriage proposals, asking for a date, and starting a project. These very basic motives are called 'Speech Acts' (Austin, 1962). Pragmatics is about utterance production, the intention of the producer which leads to the receptor's interpretation under cultural and social conventions. The latter dictates instances of polite and impolite social events. The notions of politeness and impoliteness have raised controversial debates over their proper definition. Watts (2003) contends that: "(im)politeness is a term that is struggled over at present, has been struggled over in the past and will, in all probability, continue to be struggled over in the future" (Watts, 2003.p.9). In their book "Politeness, Some Universals of Language Usage, in 1987" Brown and Levinson introduced 'Politeness Theory' also known as "Face-saving Theory". Lakoff (1975) argues that politeness is about "those forms of behavior which have been developed in societies in order to reduce friction in interpersonal interaction" (Cited in Watts, et al., 2005, p. 45). The Model is an attempt to understand how polite utterances convey meaning to establish social harmony and preserve the hearer's 'Face' in a conversation. Brown and Levinson adopted Goffman's notion of 'face'. Thus, face represents the positive public image a person likes to maintain in a social interaction. In short, politeness saves 'face', whereas, impoliteness attacks it (Goffman, 1967). Parallel to politeness theory, Culpeper (1996) came up with a counter model that considers social disharmony and seeks conflict. He refers to the "Impoliteness Model" as 'the Opposite' or 'the parasite' of politeness. According to him, "Impoliteness Comes about when: (1) the speaker communicates face-attacks intentionally. Or, (2) the hearer perceives and/or constructs behavior as intentionally face-attacking. Or, a combination of (1) and (2)." (Culpeper, 2005. p. 38). Intentionality happens to be of a paramount importance to understand what triggers impoliteness usage. In his model, Culpeper (2010) identifies nine types of impoliteness formulas which are insults, pointed criticism and complaints, challenging/unpalatable questions and presuppositions, condescensions, message enforcers, threats, Silencers, dismissals, and negative expressives. The full model is going to be further explained in details below.

\section{Gender and Impoliteness}

Gender refers to the socially acceptable behaviors of a male or female in a given social and cultural context (Ahmed and Abdul Wahab, 2014).In her remarkable book 'Language and Women's place', Lakoff (1973b) distinguishes women's speech 
as more polite than the one of men. She declares that "men in this culture tend to impose their value judgments on everyone, so that the men's way of doing things becomes the 'good way', and the women's way the bad way." She reinforces the idea that "women will tend to speak with reference to the rules of politeness, conversational implicature, and interpersonal exploration; men will tend to speak with reference to rules of conversation and straight factual communication." ( Lakoff, 1973b. p.74). She adds that men's monopoly over institutional discourse, about masculinities and femininities, leads to females' relegation to a secondary position. Similarly, Holmes (1995) proposes that men and women do not speak alike because they were socialized differently. Tannen (1990) explains in her book 'You just don't Understand!" that women use language to build connections; whereas; men seek conflict and competition. Works like (O'barr \& Atkins, 1980; Cameron and Coates, 1998; and Mills, 2003) have reached the same conclusions with regards to gender and (im)politeness issues.

\section{Animation as Data}

The novelty of this research dwells in the unconventional characteristics of its sample. Unlike traditional research in the fields of politeness and impoliteness which focuses on real-life social interactions; this article targets Disney modern animation movies as a source of data. To the best of the researcher's knowledge, the issue of impoliteness in Disney features has not been tackled before in terms of impolite protagonist. Elam (1980) asserts that fictional personas are created as extensions of real social agents. They are woven to perform real-life social roles. For him, it is through their linguistic choices and social interactions we come to understand what the story revolves around. To say it in other words, the genre of anime is but a fictional representation of reality. Culpeper (1998) indicates that the model of impoliteness may be applied on entertainment TV shows, fiction and films. Animation should not be any exception. To back the findings up, Lakoff (1973b) suggests that examining impoliteness caused by men to women could open up some interesting debates. This study wants to uncover such practices in Disney interactions between males and females lead characters. The aim is to unveil how power relations are enacted and re/produced.

\section{Frozen (2013)}

The story revolves around the princesses of Arendale, Elsa and Anna. Elsa was born with Ice powers; therefore; her parents isolated her from Anna and everyone else so she does not cause them harm. Princess Anna is unaware of her elder sister's magical powers. She is confused about why her sister shuts her out all the time. The king and queen pass away and left Elsa heir of the thrown. In coronation day, Anna meets Prince Hans, of the Southern Isles, and falls immediately in love with him. They announced their engagement the very same day. When Elsa finds out; she snaps and has a fight with Anna who pushes her too hard. Elsa accidentally uses her powers in public and runs to the mountains afraid for her life after the guards haunted her. Here, Anna chooses to find her sister and put an end to the eternal winter she launched. While seeking Elsa, Anna meets Kristoff and his reindeer. She asks him to take her up the North Mountain. During their journey, Anna and Kristoff face many dangers and manage to break through. Yet, the two drive each other crazy with arguments about true love. By the end of the feature, Elsa freezes Anna's heart undeliberately. The trolls tell Kristoff that only an act of true love could save her life. He immediately takes her to Hans who turns to be a malicious opportunist prince. Hans used Anna's naivety to marry her, kill Elsa, and take the thrown. Fortunately enough with some help from Olaf, Anna gets to save Elsa's life as the ultimate act of love and sacrifice. There is such a nice twist from the true love's kiss to a bond of sisterhood. Anna, nevertheless, gets her happy ending with Kristoff. They lived happily ever after!

\section{Moana (2016)}

Moana (2016) unfolds the story of the Polynesian Folklore. Moana, the Chief's daughter, ventures the blue ocean and sails beyond the reef in order to fulfill her dust. Baby Moana was chosen by the ocean to restore the heart of the Mother Island Te Fiti which was stolen 1000 years ago by Maui. By ripping Te Fiti's heart off, the Lava Monster 'Te Ka' was created. She defeated Maui in their battle and outcast him to a deserted island without his magical fishhook. Moana grew up listening to her grandmother's myths of Te Ka sucking the life from the Pacific Islands seeking Te Fiti's heart. Once, the curse reaches her Island, Moana challenges the will of her overprotective father and his hopes for her to be the next Leader of the people 
of Motunui. Moana gains help from her notorious grandmother and finds her ancestor's canoes. "She sails across the ocean, finds Maui, Makes him board her boat and delivers the heart of Te Fiti". When Moana and Maui finally meet their relationship is electrified, for both of them wanted to appear stronger, heroic and more assertive. In their race towards power, they argued and fought a lot but the obstacles they faced and overcame together made them closer. The story ends when Moana restores the heart herself and discovers that Te Ka is Te Fiti. By the end of the movie, Moana saves her home island and resurrects Mother Nature. She returns home to become the Chief of her people as her father wished; while Maui gets away with stealing the heart and receives love from humans for he helped restore it. The protagonists did not share a romantic flame but they sure held a good friendship.

\section{Methodology}

\section{Population and Sample}

The research at hand focuses on the population of full-length animated movies from Disney productions. These films were released between the time slots expending from 2013 till 2016. The research is interested in fully animated films that entered the box-office as highest grossing ' $G$ rated'. This overlooks releases like Beauty and the Beast 2017, the Little Mermaid 2018, where animation is merged with real-life actors. A sample of two Disney films met the research requirements:

They portray male and female protagonists.

They are ' $G$ rated' films in the box-office

They are fully animated.

(Table 1: Disney Princess films) demonstrates the films to be studied, the characters under scrutiny, the era they belong to, date of release, and the box-office profits as cited in (www.boxofficemojo.com 2018 ). This serves the global purpose of the study which seeks to trace impoliteness strategies and gender differences among protagonists. We are interested in how the impolite communicative speech events by both genders maintain power relations.

Table 1: Disney Princess Films

\begin{tabular}{llcll}
\hline Disney Era & Film & Female & Male & Box-office \\
\hline Modern & Frozen (2013) & Anna & Kristoff & $\$ 400.738 .009$ \\
& Moana (2016) & Moana & Maui & $\$ 248.757 .044$ \\
& & & & \\
\hline
\end{tabular}

\section{The derived hypotheses in this study are stated as follows:}

H1: Disney modern lead-characters re/produce impolite behaviors.

H2:

Females opt for impoliteness to claim power.

Males' impoliteness is a practice of their masculine dominance.

\section{Data Collection and Categorization}

Data were collected as the researcher re/view the Disney features attempting to transcribe and code the variables under scope. The animations under scrutiny were re/watched for six times. Some themes were submerging and the researcher did not want to exclude them without checking if these themes might be re-occurring in both films which render them worth studying. The measurement instruments were inspired from the literature reviewed earlier. Female and male protagonists were analyzed apart from one another. The movies content was coded based on male and female lead characters impolite utterances and gender performances. The researcher tried to cover up all the instances loaded in the films' content. This article relies on Culpeper's 'Model of Impoliteness Formulae' (2010) as to measure the types and 
causes of impoliteness use by Disney modern male and female protagonists. Culpeper classifies the strategies of impoliteness as follows: (Culpeper, 2010, p. 3242-3243)

Insults:

\section{Personalized negative vocatives}

[you][ fucking/ rotten/ dirty/ fat/ little/ etc.]

[Moron/ fuck/ plonker/ dickhead/ berk/ pig/ shit/ bastard/ loser/ liar/ minx/ brat/ slut/ squirt/ sod/ bugger, etc.] [you]

\section{Personalized negative assertions}

- [you] [are] [so/such a] [shit/ stink/ thick/ stupid/ bitchy/ bitch/ hypocrite/ disappointment/ gay/ nuts/ nuttier than a fruit cake/ hopeless/ pathetic/ fussy/ terrible/ fat/ ugly/ etc.]

- [you] [can't do] [anything right/ basic arithmetic/ etc.]

- [you] [disgust me/ make me] [sick/ etc.]

\section{Personalized negative references}

- [your] [stinking/ little] [mouth/ act/ arse/ body/ corpse/ hands/ guts/ trap/ breath/ etc.]

\section{Personalized third-person negative references (in the hearing of the target)}

- [the] [daft] [bimbo]

- [she] ['s] [nutzo]

\section{Pointed criticisms/complaints}

- [that/ this/ it] [is/ was] [absolutely/ extraordinarily/ unspeakably/etc.] [bad/ rubbish/ crap/ horrible/ terrible/ etc.]

\section{Challenging or unpalatable questions and/or presuppositions}

- Why do you make my life impossible?

- Which lie are you telling me?

- What's gone wrong now?

- You want to argue with me or you want to go to jail?

Condescensions (see also the use of "little" in Personalized negative references)

- [that] ['s/is being] [babyish/ childish/ etc.]

\section{Message enforcers}

- Listen here (preface)

- You got [it/that]? (tag)

- Do you understand [me]? (tag)

\section{Dismissals}

- [go] [away]

- [get] [lost/ out]

- [fuck/ piss/ shove] [off] 


\section{Silencers}

- [shut] [it]/[your] [stinking/ fucking/ etc.] [mouth/ face/ trap/ etc.]

- shut [the fuck] up

\section{Threats}

- [l'I//'m/we're] [gonna] [smash your face in/ beat the shit out of you/ box your ears/ bust your fucking head off/ straighten you out/etc.] [if you don't] [X]

- [X] [before I] [hit you/ strangle you]

Negative expressives (e.g. curses, ill-wishes)

- [go] [to hell/hang yourself/fuck yourself]

- [damn/fuck] [you]

\section{Analysis of Disney Features}

Frozen (2013)

1-Now, back up while I deal with this crook, here! (M/ dismissal /show of power/F)

2- Seriously, were you raised in a barn? (M/pointed criticism/ disappointment/F)

3-Get your feet down! (M/complaint/disapproval/F)

4-Wait! You got engaged to someone you just met that day? (M/pointed criticism/panic/F)

5-didn't your parents ever warn you about strangers? (M/presupposition/disagreement/F)

6-Oh yeah! What if he picks his nose? (M/ Challenging question/ desire to provoke/F)

7- Stop talking! (M/silencer/show power/F)

8- $Y u$ are gonna kill yourself! (M/condescension/helplessness/F)

9- Excuse me, Sir. He is a prince. (F/message enforcer/disapproval/M)

10- Are you some sort of love expert? (F/Challenging question/disagreement/M)

11- Hey! You... (F/insult/anger/M)

12- Don't you dare! (F/threat/threat to the face/M)

13- You are destructing me. (F/complaint/dispute/M)

14- I'm just blocking you out. (F/Silencer/show of power/M)

15- I mean sure; I will let you tag along! (F/condescension/wish to entertain/M)

16-Nobody wants to be alone except maybe you! (F/presupposition/sorrow/M)

\section{Moana (2016)}

1- Little girl, I am a hero. (M/condescension/show of power/F)

2- You don't even know how you feel, it's adorable! (M/pointed criticism/helplessness/F)

3-It's nice to see that humans never change (M/presupposition/ wish to entertain/F)

4- Don't mess with Maui when he is on the breakaway (M/threat/threat to the face/F)

5-Alright, get over it! We gotta move. (M/dismissal/desire to provoke/F) 
6-Muscle up Buttercup! (M/Insult/helplessness/F)

7- Get it away from me. (M/threat/panic/F)

8- You are not my hero. (F/condescension/show of power/M)

9-Let me out you lying slimy son of a ... (F/insult/anger/M)

10-what is the problem? Are you afraid of it? (F/challenging question/desire to provoke/M)

11-you will be a hero. That's what you are about, right? (F/message enforcer/disappointment/M)

12- May be you were, but now you're the guy who stole the heart of Te Fiti. (F/condescension/sorrow/M)

13- You are a bad person (F/pointed criticism/disapproval/M)

14-It's disgusting. Ewww! (F/pointed criticism/ dispute/M)

15- Do you have a shark head cause I... (F/presupposition/wish to entertain/M)

16-Get up! (F/message enforcer/desire to provoke/M)

\section{Findings}

\section{Table 02: Types of Impoliteness Strategies Employed by Female and Male Characters}

\begin{tabular}{lcccr}
\hline Types of Strategy & \multicolumn{2}{c}{ Female } & \multicolumn{3}{c}{ Male } \\
\hline Insults & 6 & $7.4 \%$ & 19 & $9.6 \%$ \\
Pointed Criticism/ Complaints & 12 & $14.9 \%$ & 43 & $21.8 \%$ \\
Presupposition/Challenging, & 34 & $42 \%$ & 31 & $15.7 \%$ \\
Unpalatable Questions & & & & \\
Condescensions & 10 & $12.3 \%$ & 51 & $25.8 \%$ \\
Message Enforcers & 10 & $12.3 \%$ & 17 & $8.6 \%$ \\
Dismissals & & & 9 & $4.6 \%$ \\
Silencers & 4 & $4.9 \%$ & 9 & $4.6 \%$ \\
Threats & 4 & $4.9 \%$ & 16 & $8.1 \%$ \\
Negative Expressives & $1.2 \%$ & & $1.01 \%$ & \\
Total & 81 & & 197 &
\end{tabular}

*In the parenthesis( ) the first part indicates the speaker's gender, the second refers to the type of impoliteness, the third to the triggers of impoliteness, and the fourth one stands for the hearer's gender.

The analysis, of impoliteness strategies expressed by males and females, demonstrates that female protagonists tend to use more challenging, unpalatable questions and presuppositions (42\%) accompanied with a high use of message enforcers (12.3\%); whereas; their male counterparts employ more condescensions $(25.8 \%)$ alongside with complaints and pointed criticism (21.8\%). Unlike males, Females do not at all opt for dismissals. They rarely use silencers, threats, and negative expressives.

\section{Table 2: Triggers of Impoliteness}

\begin{tabular}{lrcrr}
\hline Triggers & Female & \multicolumn{3}{c}{ Male } \\
\hline Anger & 10 & $11.23 \%$ & 8 & $5.2 \%$ \\
Dispute, disagreement, disapproval & 25 & $20.08 \%$ & 30 & $19.5 \%$ \\
A threat to the face & 6 & $6.7 \%$ & 13 & $8.4 \%$ \\
Show power & 18 & $20.2 \%$ & 33 & $21.4 \%$ \\
Bewilderment, panic & 3 & $3.4 \%$ & 7 & $4.5 \%$ \\
Helplessness, sorrow, disappointment & 12 & $13.5 \%$ & $16.9 \%$ & - \\
Jealousy & - & & - & \\
\hline
\end{tabular}




\begin{tabular}{lrccc}
\hline Desire to provoke & 10 & $11.23 \%$ & 10 & $15.6 \%$ \\
Wish to entertain & 5 & $5.6 \%$ & 5 & $8.4 \%$ \\
Total & 89 & & 154 &
\end{tabular}

The analysis indicates that dispute, disagreement, and disapproval $(28.08 \%)$ with a high anger rate $(11.23 \%)$ are the main causes behind female's impoliteness. Jealousy seems to be off the grid. Yet, both genders happen to use impoliteness at about the same frequency to show power (21.4\% for males and $20.2 \%$ for females). Male characters score higher in performing a threat to the face, desire to provoke, express their disappointment, wish to entertain, and bewilderment. On the other hand, females have a lower score of panic (3.4\%).

\section{Research Limitations and Future Research}

As for all research this study is no exception, it confronted limitations. Analyzing two Disney modern princess films do not provide us with a sense of foreseeing what could be next for Disney, in terms of character discursive and gender performances. Another interesting scope, for further research, is the inclusion of secondary characters (im)polite usage and its impact on the audience. Other related avenues for future research would be to check whether children recognize the extent to which strategic politeness and impoliteness, together as pragmatic practices, set power relations and gender hierarchies. Additional research is recommended to explore the Para-linguistic features like prosody, body language and the study of context. We need not only look at the micro-level but also take it beyond the utterances. Moreover, it is of high importance to study other Disney releases and cartoons to have a better understanding of what Disney is teaching our children and what ideologies it diffuses through its iconic characters.

\section{Conclusion}

The research findings point out that both genders perform impoliteness as a communicative speech event to convey certain feelings, emotions, and attitudes. Female protagonists use less impolite utterances than men. Thus, we can say that females prove to be more prudent than males not to enunciate impoliteness. This result indicates the subjugation of females to a secondary position and underpins men as the dominant language users. Female lead characters are more likely to express presuppositions and challenging questions (42\%). They also utilize message enforcers (12.3\%). It is more common for males to articulate condescensions $(25.8 \%)$, complaints or pointed criticism $(21.8 \%)$, and threats $(8.1 \%)$. Insults are opted for by both genders with slight difference males $(9.6 \%)$ and females $(7.4 \%)$. The same applies to Silencers, where females utter (4.9\%) and males (4.6\%). Furthermore, Disney princesses never perform dismissals; however, males use (4.6\%). The results suggest that the heroines produce impoliteness to express their challenge, anger, disapproval and claim power; whereas; Disney heroes utter impoliteness to threat, show power, provoke, wish to entertain, and express disappointment or panic. When it comes to power relations, Males use impolite speech acts to seek dominance, struggle, and competition. Nevertheless, females make use of it to contend their inferior position by showing power, challenge, and disapproval.

To conclude with, the findings state that Disney heroines are more polite than males. They go carefully in performing impolite speech acts for they were socialized to conform to traditional femininities. Males' impoliteness goes unperceived as a natural practice of their masculine dominance 'Boys will always be Boys!' The results are consistent with the reviewed literature (Lakoff, 1973; Tannen, 1990; Holmes, 1995). It is important to signal that females might not be persistent articulators of impoliteness; but they sure are subject to it. Males perform impoliteness to belittle and condense females' roles and value in fiction as an extension to real social life (Bettelheim, 1991). Gender inequalities transcend from everyday life to children entertainment legitimizing patriarchy (Lederer, 2012). We should bear in mind that the outcomes are found from a small sample of Disney modern princess films. Other animations and cartoons from the three Disney eras (classic, renaissance and modern) can help provide a better understanding of the impolite language usage. The objective is to make this conglomerate media genre healthier for child consumption. For children emulate gender norms and linguistic productions from those whom they see as admirable references (Binkley, 2016). The Walt Disney Corporation must step up and hold responsibility for the effect it has on children as a socializing and educational media agent. Its profits should not always be its primary concern than its ethical stance (Giroux, 2010). 


\section{References}

[1] Austin, John. L., (1962). How to Do Things with Words. Oxford: Oxford University Press.

[2] Ahmed, S., Abdul Wahab, J. (2014). Animation and Socialization Process: Gender Role Portrayal on Cartoon Network. Journal of Asian Social Science; Vol. 10, No. 3; 45-53.

[3] Azmi, N J., Radzuwan Ab Rachid., Mairas Abd Rahman., Basirah Safawati ,Z. (2016). Gender and Speech in a Disney Princess Movie. pp.2. International Journal of Applied Linguistics \& English Literature. Vol.05 No.6.

[4] Bettelheim, B. (1991). The Uses of Enchantment: The Meaning and Importance of Fairy Tales. Harmondsworth: Pinguin, 1991.

[5] Binkley, M. (2016). An Argument on Disney and Psychological Development. Journal of Undergraduate Research.10.1.

[6] Brown, Penelope. \& Levinson, S.C. (1987). Politeness: Some Universals in Language Usage. (2 ${ }^{\text {nd }}$ ed.). Cambridge: Cambridge University Press.

[7] Chen, H.P. (2006). The Significance of Manga in the Identity construction of Young American Adults: A Lacanian Approach." Marylyn Zurmuehlin Working Papers in Art Education. Iss.1, Article 2.

[8] Coates, J., Cameron, D. (1998).Women in Their Speech Communities. (eds). London: Longman.

[9] Culpeper, J. (1996). Towards an Anatomy of Impoliteness. Journal of Pragmatics 25: 349-367.

[10] Culpeper, J. (1998). (Im)politeness in Drama. In Studying Drama: From Text to Context, Jonathan Culpeper, Mick Short, and Peter Verdonk (eds.), 83-95. London: Routledge.

[11] Culpeper, J. (2005). Impoliteness and Entertainement in the Television Quiz Show: The Weakest Link. Journal of Politeness Research: Language Behaviour, Culture 1:35-72.

[12] Culpeper, J. (2010). Conventionalized Impoliteness Formulae. Elsevier Journal of Pragmatics, 42:3242-32430

[13] Elam, K. (1980). The Semiotics of Theatre and Drama. 136-137. London \& New York: Methuen.

[14] England, D.E., Descartes, L., Collier-Meek, M.A.(2001). Gender Role Portrayal and the Disney Princess. Journal of Sex- Roles,

[15] 64,555-567. http://dx.doi.org/10.1007/s11133-011-9930-7.

[16] Giroux, H. A. (2010). The Mouse that Roared: Disney and the End of Innocence. ( $2^{\text {nd }}$ ed.). Lauhan, MD: Rowman \& Littlefield Publishers, Inc.

[17] Goffman, E. (1967). Interaction Ritual. Chicago: Aldine Publishing.

[18] Guizerix, J. (2013). From Snow White to Brave: The Evolution of the Disney Princess. Florida Atlantic University.

[19] Holmes, J. (1995). Women, Men and Politeness. London: Longman.

[20] Lacroix, C. (2004). Images of Animated Others: The orientalization of Disney's Cartoon Heroines from the Little Mermaid to the Hunchback of Notre Dame. Popular Communication; 2 (4), 213-229.

[21] Lakoff, R. (1972). Language and Women's Place. New York: Harper and Row. As cited in: Watts, R., Ide, S. \& Ehlich, K. (Eds.). (2005). Politeness in Language: Studies in its History, Theory, and Practice. (2 ed.). Berlin: Walter de Gruyter.

[22] Lakoff, R. (1973b). Language and Women's Place, Language in Society. 2, 45-80.

[23] Lederer, E. M. (2012). Passively Ever After: Disney's Cinematic Abuse in Beauty and the Beast. East Carolina University.

[24] Lippi-Green, R. (2012). English with an Accent: Language, Ideology and discrimination in the United States. (2 ${ }^{\text {nd }}$ ed.). London; New York: Routlege.

[25] Mills, S. (2003). Gender and Politeness. Cambridge: Camridge University Press.

[26] O'Barr , W. M., \& Atkins, B. K.( 1980). 'Women's Language' or 'Powerless Language?'. In S. McConnell-Ginet, N. Borker,\& R. Thurman (eds.), Women and Language in Literature and Society, New York: Praeger, 93-110.

[27] Romer, N. (1989). The Sex-Role Cycle: Socialization from Infancy to Old Age. Old Westbury, New York: The Feminist Press.

[28] Soares, T.O. (2017). Animated Films and Linguistic Stereotypes: A Critical Discourse Analysis of Accent Use in Disney Animated Films. BSU Master's Theses and Projects. Item 53.

[29] Stalnaker, R. C. (1972). Pragmatics. In Donald and Gilbert Herman (eds.), Semantics of Natural Language. Dordrecht: Reidel.

[30] Tannen, D. (1990). You Just Don't Understand. New York: Ballentine Books.

[31] Thomas, T. L., Zerbinos, E. (1995). Gender Roles in Animated Cartoons: Has the Picture Changed in 20 Years?. Sex Roles 32: 651-673. 
[32] Towbin, M., Haddock, S., Zimmerman, T., Lund, L., \& Tanner, L. (2003). Images of Gender, Race, Age,and Sexual Orientation in Disney Feature-length Animated Films. Journal of Feminist Family Therapy, 15(4), 19-44

[33] Van Dijk, T.A. (1996). Discourse, power and Access. In Caldas-Coulthard, C. R., \& Coulthard, M. (Eds.), Texts and practices: Readings in critical discourse analysis. p. 84. London: Routledge.

[34] Watts, Richard J. (2003). Politeness: Key Topics in Sociolinguistics. p. 9. Cambridge: Cambridge University Press.

[35] Wholwend, K.(2012). "Are you Guys Girls?": Boys, Identity texts. and Disney Princess Play. Journal of Early Childhood Literacy, 12,3-23.

[36] Wieresma, Beth.A.,(2000)."The Gendered World of Disney: A content Analysis of Gender Themes in Full-length Animated Disney feature Films". Theses and Dissertations. 1906.

[37] www.boxofficemojo.com . Retrieved from https://www.boxofficemojo.com/search/?q=moana , https://www.boxofficemojo.com/search/?q=frozen . Novemeber 12, 2018. 